\title{
Planthopper Transmission of Ramu Stunt Virus, a Tenuivirus Causing the Sugarcane Disease Ramu Stunt, and its Distribution in Papua New Guinea
}

\author{
Kathryn S. Braithwaite, ${ }^{1, \dagger}$ Leka Tom, ${ }^{2}$ and Lastus S. Kuniata ${ }^{2}$ \\ ${ }^{1}$ Sugar Research Australia Limited, Indooroopilly, Queensland 4068, Australia \\ ${ }^{2}$ Ramu Agri Industries Limited, Lae, Morobe Province, Papua New Guinea
}

\begin{abstract}
Ramu stunt is a serious disease of sugarcane, currently only reported from Papua New Guinea. It is found in both commercial sugarcane grown on the Ramu Agri Industries Limited (RAIL) estate and in chewing canes (Saccharum officinarum $\mathrm{L}$.) grown in village gardens. The vector of Ramu stunt disease is the island sugarcane planthopper, Eumetopina flavipes Muir. Here we report on the successful transmission of Ramu stunt using E. flavipes and verify that the disease is caused by Ramu stunt virus, a virus with homology to the genus Tenuivirus. Diagnostic reverse transcription PCR

screening, with partial genome sequencing and viral protein characterization, was used for confirmation. Disease surveys were undertaken on the RAIL estate, along roadsides, and in village gardens in parts of Papua New Guinea. When the disease was identified, partial genome sequencing of the virus was performed to assess the extent of genome variability among isolates. The disease was less common than predicted from early surveys based on symptoms alone, and genotypic variation was associated with geographic location.
\end{abstract}

The island of New Guinea is a center of diversity for three species in the genus Saccharum. S. robustum Brandes \& Jesw. ex Grassl is found in the wild on mud flats and river banks, whereas S. officinarum L. and $S$. edule Hassk. are cultivated species widely grown in small plots in village gardens (Daniels and Roach 1987). Modern commercial sugarcanes are interspecific hybrids between S. officinarum and $S$. spontaneum L. There were no commercial sugarcane crops in Papua New Guinea until 1979 when a plantation was established at Ramu Sugar (now Ramu Agri Industries Limited [RAIL]) in the Ramu Valley, Madang Province (5.97 $\left.\mathrm{S}, 145.89^{\circ} \mathrm{E}\right)$. The sugarcane disease Ramu stunt was first recognized in 1985 to 1986 when poor yields, plant death, and severe stunting became evident in the commercial crops, almost destroying the fledgling sugarcane industry. The cultivar Ragnar, which at the time comprised 85 to $90 \%$ of the commercial crop, was highly susceptible (Eastwood 1990; Waller et al. 1987). Ramu stunt is characterized by reduced growth rate, stunting, poor ratooning, and various leaf symptoms, the most diagnostic being pale yellow-green stripes of irregular length and width.

Several extensive surveys for sugarcane pests and diseases were undertaken through parts of Papua New Guinea, Indonesia, and northern Australia between 2001 and 2003; these surveys included sampling for Ramu stunt disease (Magarey et al. 2002, 2003, 2004). The cultivated sugarcanes $S$. officinarum (chewing cane) and $S$. edule (pit pit) in local village gardens were the main focus, although $S$. robustum and $S$. spontaneum growing along roadsides and riparian areas were also examined. The surveys recorded that Ramu stunt disease was widespread in Papua New Guinea, but diagnosis was made only on the basis of leaf symptoms, which had always been considered variable (Rauka et al. 2005; Waller et al. 1987).

${ }^{\dagger}$ Corresponding author: K. S. Braithwaite;

kbraithwaite@sugarresearch.com.au

Funding: This research was supported by funding from Sugar Research Australia (projects 2009033 and 2015046) and the Queensland Government Department of Agriculture and Fisheries, with earlier funding from the Bureau of Sugar Experiment Stations and the Sugar Research and Development Corporation.

The author(s) declare no conflict of interest.

Accepted for publication 13 May 2019.

(C) 2019 The American Phytopathological Society
Ramu stunt is still present at RAIL but is managed through the planting of resistant cultivars (Rauka et al. 2005). Resistance screening trials are run on the estate to obtain resistance data for Papua New Guinea-bred (with the PN designation) and imported cultivars (Kuniata et al. 2010). The disease is a major biosecurity risk to nearby sugarcane industries, particularly Australia and Indonesia, and restricts the safe movement of sugarcane germplasm from Papua New Guinea. In Australia, Ramu stunt is considered a high-priority exotic pest of sugarcane and classified as a Category 2 Emergency Plant Pest, meaning that it would have a nationally significant economic or environmental impact (Plant Health Australia 2016). Australian and RAIL sugarcane pathologists have had a long collaboration on research into Ramu stunt, being jointly involved with diagnostic test development, disease surveys, and resistance screening of both Australian and Papua New Guinea sugarcane cultivars and elucidating disease transmission mechanisms. These activities were possible because of a long-term funding commitment from RAIL and the Australian sugar industry from 2009 to 2017.

When the disease was first recognized, the causal agent was unknown but suspected to be a virus or phytoplasma (Cronjé et al. 1999; Jones et al. 1989; Suma and Jones 2000). Subsequent research identified a virus associated with the disease that had homology to known and proposed members of the viral genus Tenuivirus (Braithwaite et al. 2007). A preliminary diagnostic reverse transcription (RT)-PCR test was developed based on a sequence with homology to tenuivirus RNA-dependant RNA-polymerase. Further genome sequencing allowed for the development of an improved diagnostic test, targeting the genome region suspected to code for the disease-specific protein, also known as the major noncapsid protein (Braithwaite et al. 2012). The full genome sequence has since been obtained by Mollov et al. (2016). BLAST analyses confirmed that the virus was most closely related to members of the genus Tenuivirus and Mollov et al. (2016) proposed that the virus be provisionally named Ramu stunt virus (RmSV).

The vector of Ramu stunt disease is the island sugarcane planthopper Eumetopina flavipes Muir (Hemiptera: Delphacidae). This was established by Kuniata et al. (1994) who carried out preliminary transmission trials using a range of insects common at RAIL. Results suggested Eumetopina sp. as the only vector. The role of Eumetopina sp. was confirmed when adults and nymphs bred on Ramu stuntdiseased sugarcane were introduced to Ragnar plants covered with polyamide mesh screens. Test plants showed Ramu stunt-like symptoms within 9 to 12 weeks. Because the work of Kuniata et al. (1994) was carried out long before the molecular characterization of the 
disease, confirmation that a tenuivirus-like agent is the cause of Ramu stunt disease and is vectored by E. flavipes had yet to be demonstrated.

This study describes a caged-insect transmission experiment carried out at RAIL where E. flavipes was used to transmit the causal agent of Ramu stunt to disease-free sugarcane. Transmission success and confirmation was monitored by symptom observations, diagnostic RT-PCR screening, partial genome sequencing, and viral protein separation. The diagnostic RT-PCR test was used to screen survey samples kept in long-term storage to provide a more accurate picture of the distribution of Ramu stunt disease in Papua New Guinea. We then used genome sequencing to assess diversity of the virus across Papua New Guinea.

\section{Materials and Methods}

Diagnostic testing. The RmSV primers used in the study are listed in Table 1. Primer pair RSC1fFwd-RSC1eRev was used for routine gel-based RT-PCR screening of RmSV. This primer pair amplifies a product of $352 \mathrm{bp}$ from open reading frame 1 on RNA 6, suspected to code for the major noncapsid protein. As the project progressed, a second diagnostic primer set (RSNCPaF-RSNCPcR, $340 \mathrm{bp}$ ) was designed to detect novel isolates of RmSV identified during surveys. An early generation diagnostic test (KB20Afwd-KB36Arev, $1,027 \mathrm{bp}$ ) based on the RNA-dependant RNA-polymerase coding region (Braithwaite et al. 2007) was used for additional confirmation of successful transmission.

Diagnostic screening was combined with an endogenous test to check RNA quality. For sugarcane leaves, we used a phosphofructokinase combination (ScPFK5F1-ScPFK5R1; Zhu et al. 2013), able to amplify both DNA (433 bp) and RNA (233 bp) in the one reaction. The endogenous test to check for E. flavipes template quality was based on the cytochrome oxidase I (COI) primer combination LCO1490-HCO2198 (Folmer et al. 1994).

Two-step RT-PCR was performed on a Mastercycler proS (Eppendorf, Hamburg, Germany) thermocycler. We used the ImProm-II Reverse Transcription System (Promega, Madison, WI) and a program of $25^{\circ} \mathrm{C}$ for $5 \mathrm{~min}, 42^{\circ} \mathrm{C}$ for $60 \mathrm{~min}$, and $95^{\circ} \mathrm{C}$ for $5 \mathrm{~min}$ for RT. PCR amplification with GoTaq Green Master Mix (Promega) used a cycling program of $95^{\circ} \mathrm{C}$ for $3 \mathrm{~min}$, followed by 35 cycles of $95^{\circ} \mathrm{C}$ for $30 \mathrm{~s}, 58^{\circ} \mathrm{C}$ for $30 \mathrm{~s}$, and $72^{\circ} \mathrm{C}$ for $30 \mathrm{~s}$, and then a final cycle of $72^{\circ} \mathrm{C}$ for $10 \mathrm{~min}$. Amplified products were resolved on $1.5 \%$ agarose gels and visualized with SYBR Safe (Invitrogen, supplied by Thermo Fisher Scientific, Waltham, MA).

Transmission experiment. The experimental system established at the research facilities on the RAIL estate in 2014 consisted of three cages, each approximately $1.5 \mathrm{~m} \times 1.5 \mathrm{~m} \times 2 \mathrm{~m}$ high. Two cages were covered in high-quality white insect-proof Biomesh (Redpath, Bendigo, VIC, Australia). One cage had no openings and contained the control uninfected plants. The second cage contained the initially uninfected test plants and had openings to allow the introduction of the insects that were to transmit the virus. The test and control plants were the sugarcane cultivar Ragnar, sourced from the Sugar Research
Australia (SRA) quarantine glasshouse in Brisbane, Australia, and considered disease free. At the start of the experiment, the plants did not show flecking, streaking, or stunting and diagnostic testing confirmed their disease-free status. Five plants were established in each cage. The third cage, the source cage, was covered in green shade cloth and contained Ramu stunt-infected Ragnar sourced from spreader rows in a Ramu stunt resistance screening trial at block CN107 on the RAIL estate. The plants were confirmed positive by diagnostic testing. In all three cages, sugarcane cuttings were planted directly into the ground and the cages were placed immediately over the top. The cages were placed several meters apart and thus subjected to the same general environmental conditions. At the commencement of the trial (March), eight random leaves from each cage were sampled for diagnostic testing and the test and control plants were cut at ground level (ratooned) to provide fresh young regrowth for the experiment.

E. flavipes was collected by aspiration directly from the field over 2 months (March to May) from an area with no obvious Ramu stunt disease (RAIL estate block ES104). A random subsample of 40 individuals was kept aside for diagnostic testing to ensure they were free from $\mathrm{RmSV}$. The remainder (660 individuals) were introduced to the source cage to feed on the infected sugarcane and acquire the virus. The insects were collected by aspiration in late May and transferred to the test cage to transmit the disease. We sampled the test plants twice. In July, 2 months after the last introduction of the vector, the 4-month-old crop was inspected for visual symptoms, stalks were cut again at ground level, and leaf and planthopper samples were collected. The plants were allowed to regrow for 3 months; in October, the regrowth was inspected and harvested and leaf samples were collected. Throughout the 7-month experiment, source, test, and control plants and E. flavipes were monitored with the diagnostic combination RSC1fFwd-RSC1eRev and the appropriate endogenous test. Selected samples were also screened with KB20Afwd-KB36Arev and $\mathrm{RSNCPaF-RSNCPcR}$. The endogenous sugarcane test was included to ensure that the RNA extracted from dried irradiated leaf samples was of sufficient quality for RT-PCR.

Plant sampling. Leaf samples for diagnostic testing were collected during the transmission experiment, from commercial sugarcane cultivars grown on the RAIL estate for commercial production, in propagation nurseries, or research trials, and during disease surveys. The first extensive Papua New Guinea-wide survey that included sampling for Ramu stunt disease occurred in 2001 (Magarey et al. 2002). This survey visited the south coast (Daru Island, Morehead), western border area (Tabubil, Vanimo), north coast/northeast islands (Wewak, Manus Island, New Ireland, New Britain, RAIL), eastern coast (Popondetta, Alotau), and Port Moresby (Sorgeri). This was followed by surveys in 2002 and 2003 to neighboring Torres Strait in Northern Australia and Indonesia (Magarey et al. 2003, 2004), where Ramu stunt disease has not been recorded. Since those extensive surveys, smaller targeted surveys occurred around Goroka (Eastern Highlands Province, 2011), Madang (Madang Province, 2011), Alotau (Milne Bay Province, 2013), and along the Ramu Valley close to the RAIL estate (Madang

Table 1. PCR primers used in this study

\begin{tabular}{llll}
\hline Genome target & Primer & \multicolumn{1}{c}{ Nucleotide sequence (5' to 3') } & Reference \\
\hline $\begin{array}{l}\text { Diagnostic primer } \\
\text { RNA 6 }\end{array}$ & RSC1fFwd* & & Braithwaite et al. (2012) \\
& RSC1eRev & CTCTTCACAGCTTAGCAAAAAGCC & This study \\
RNA 6 & RSNCPaF & GTCTGCATGTTGCAGTATTAGGTC & Braithwaite et al. (2007) \\
& RSNCPcR* & TGAGATATGTCATCCTCCCACAGG & \\
RNA 1 & KB20Cfwd* & GAGCTGATATTTAGACTTAGGGTTGC & \\
Kequencing primer & KB36Arev & GTTTTACTGATATGGACAACTC & de Miranda et al. (1994) \\
All tenuiviruses & T10* & CCCGGGCGGCCGCACACAAAGTC & This study \\
RNA 6 & RSC1aRev & TCCTCCCACAGGTAGTTCAG & This study \\
RNA 6 & RSC1dFwd & GTGTTCTGAACTACCTGTGGGAGG & This study \\
RNA 6 & RSC1eFwd & GACCTAATACTGCAACATGCAGAC & \\
\hline
\end{tabular}

a Primers marked with an asterisk were used to prime the reverse transcription reaction. 
Province, 2009, 2010, 2011, 2016). The plants targeted on the surveys were the cultivated sugarcanes $S$. officinarum and $S$. edule in traditional-style gardens and wild $S$. robustum growing along roadsides and riverbanks. All survey samples that tested positive were used in the phylogenetic analysis.

In all cases, the leaves were cleaned with $70 \%$ alcohol wipes, then processed either as approximately $2 \mathrm{~g}$ of chopped leaf or 20 leaf disks punched with a paper punch. Both sample types were stored in tubes containing anhydrous granular calcium chloride (Merck, Darmstadt, Germany) as the drying agent. Because of Australian Government biological import conditions, all leaf material was subject to 25- or 50kGy gamma irradiation on arrival into Australia. Survey samples are preserved at $-70^{\circ} \mathrm{C}$ in the SRA laboratory in Brisbane, where diagnostic testing was carried out. RNA was extracted using a Qiagen RNeasy Plant Mini Kit (Qiagen, Hilden, Germany).
Eumetopina sampling. Random E. flavipes individuals collected from the transmission experiment at three timepoints $(0,2$, and 4 months) using an aspirator were transferred to $90 \%$ ethanol for preservation. They were declared on arrival to the Australian Department of Agriculture and Water Resources and no further quarantine restrictions were needed. Total nucleic acids were extracted from individuals using the proteinase $\mathrm{K}$ method described in Virtudazo et al. (2001) for single fungal pustules.

Phylogenetic analyses. All RmSV-positive survey samples, 14 commercial cane isolates collected between 2006 and 2016 from the RAIL estate, and selected transmission samples were subjected to phylogenetic analyses by sequencing the entire $1.2-\mathrm{kb}$ genome segment corresponding to viral RNA 6 (Mollov et al. 2016). In all cases, the RT reaction was primed by the primer T10 (de Miranda et al. 1994; Table 1). We used either the ImProm-II (Promega) or

Table 2. Experimental design, symptoms, and screening results for the transmission of Ramu stunt by Eumetopina flavipes

\begin{tabular}{|c|c|c|c|}
\hline Timepoint (mo) & Activity and sample & Positive RT-PCR samples/total ${ }^{a}$ & Plant symptoms \\
\hline \multirow[t]{4}{*}{0 (March) } & 1. Commence experiment & & \\
\hline & Source plants (8 leaves) & $8 / 8$ & Leaf stripes, stalks thin and stunted \\
\hline & Test plants (8 leaves) & $0 / 8$ & No leaf symptoms or stunting \\
\hline & Control plants (8 leaves) & $0 / 8$ & No leaf symptoms or stunting \\
\hline \multirow[t]{2}{*}{0 (March) } & $\begin{array}{l}\text { 2. Collect } E \text {. flavipes from field and } \\
\text { introduce to source cage }\end{array}$ & & \\
\hline & E. flavipes & $0 / 40$ & \\
\hline \multirow[t]{2}{*}{2 (May) } & $\begin{array}{l}\text { 3. Collect E. flavipes from source cage } \\
\text { and transfer to test cage }\end{array}$ & & \\
\hline & E. flavipes & $27 / 40$ & \\
\hline \multirow[t]{6}{*}{4 (July) } & 4. First inspection & & \\
\hline & E. flavipes in source cage & $16 / 40$ & \\
\hline & Source plants & $3 / 3$ & All plants chlorotic and unthrifty \\
\hline & E. flavipes in test cage & $1 / 40$ & \\
\hline & Test plants & $3 / 4$ & 3 of 4 plants had leaf symptoms \\
\hline & Control plants & $0 / 5$ & 5 plants with no symptoms \\
\hline \multirow[t]{4}{*}{7 (October) } & 5. Second inspection & & \\
\hline & Source plants & N/A & All plants dead \\
\hline & Test plants & $3 / 4$ & $\begin{array}{l}4 \text { plants had a mix of tall and stunted } \\
\text { stalks; } 2 \text { of } 4 \text { had leaf symptoms }\end{array}$ \\
\hline & Control plants & $0 / 4$ & 4 plants with no symptoms \\
\hline
\end{tabular}

${ }^{\mathrm{a}} \mathrm{RT}=$ reverse transcription and N/A = not applicable.
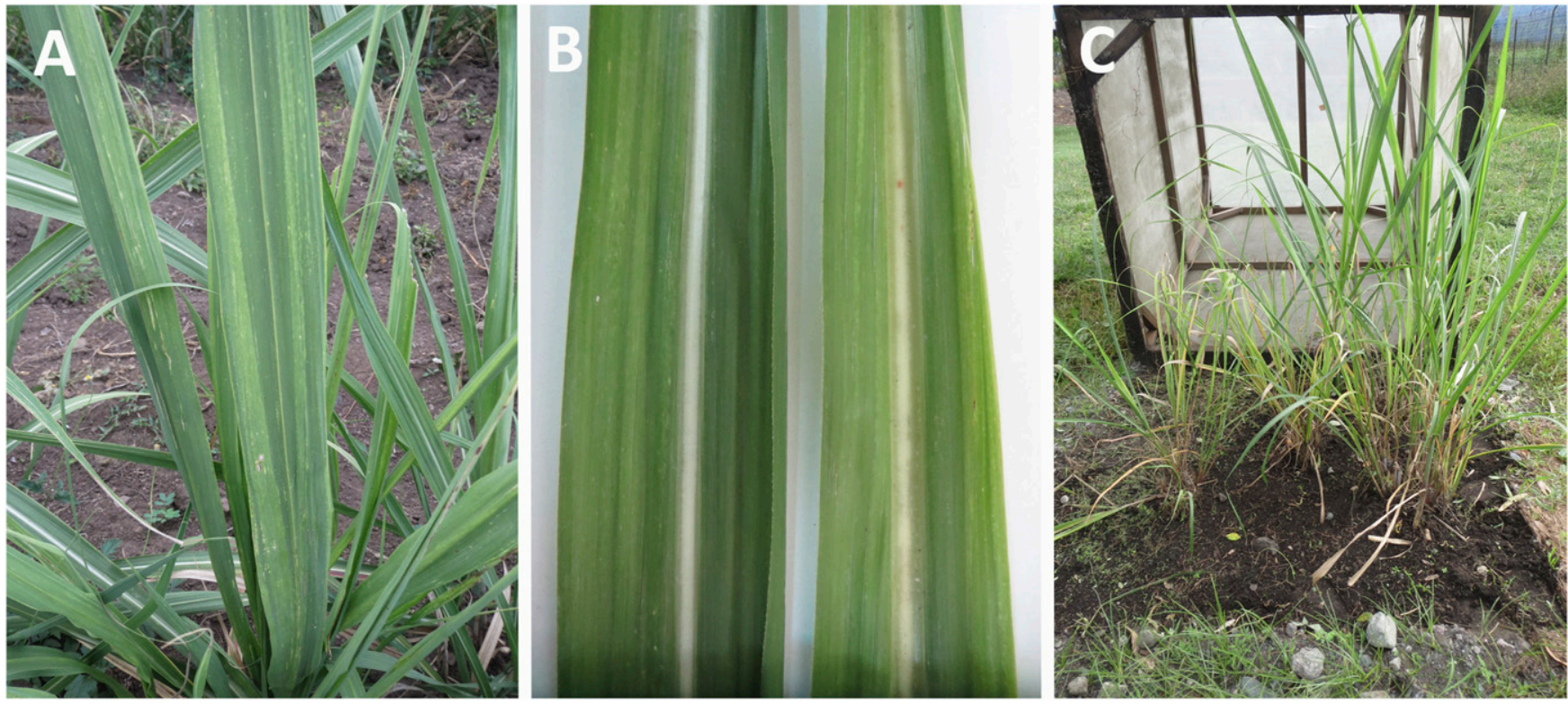

Fig. 1. Symptoms of Ramu stunt infection of sugarcane. A, Typical symptoms of Ramu stunt disease seen as pale green stripes of irregular length and width on leaves of field grown cultivar Ragnar. B, Leaf symptoms seen in transmission test plant T1 at the first inspection 2 months after exposure to viruliferous E. flavipes. C, Test plants at the second inspection displaying yellowing, grassiness, and stunting in the regrowth. The test cage has been tipped back to allow access to the plants. 
ThermoScript RNase H- (Invitrogen) system for RT. A series of internal sequencing primers were paired with T10 to amplify across the 1.2-kb region (Table 1). Amplifications for sequencing used either Pfu DNA Polymerase (Promega) or Platinum Taq DNA Polymerase High Fidelity (Invitrogen). PCR products were excised from gels and purified using the Wizard SV gel and PCR clean-up system (Promega). Sanger sequencing was performed at the Australian Genome Research Facility in Brisbane. Sequence editing, contig construction, multiple sequence alignments with ClustalW, and tree construction were performed using programs supplied in the Geneious 11.0.2 package (Biomatters Ltd., Auckland, New Zealand). The tree was generated using the Jukes-Cantor genetic distance model and unweighted pair group with arithmetic mean tree build method with 1,000 bootstraps.

Viral minipurifications. Viral purifications were performed to provide additional protein-based evidence of successful transmission. Selected transmission and survey samples were subjected to a small-scale viral purification procedure, followed by separation of the viral proteins by polyacrylamide gel electrophoresis (PAGE). The equivalent of $2 \mathrm{~g}$ of fresh leaf was ground in $35 \mathrm{ml}$ of $0.2 \mathrm{M}$ sodium citrate buffer, $\mathrm{pH} 6.5$, with added sodium diethyldithiocarbamate at $20 \mathrm{mM}$ and soluble polyvinylpyrrolidone 40,000 at $4.5 \%$. The slurry was filtered through muslin and centrifuged for $12 \mathrm{~min}$
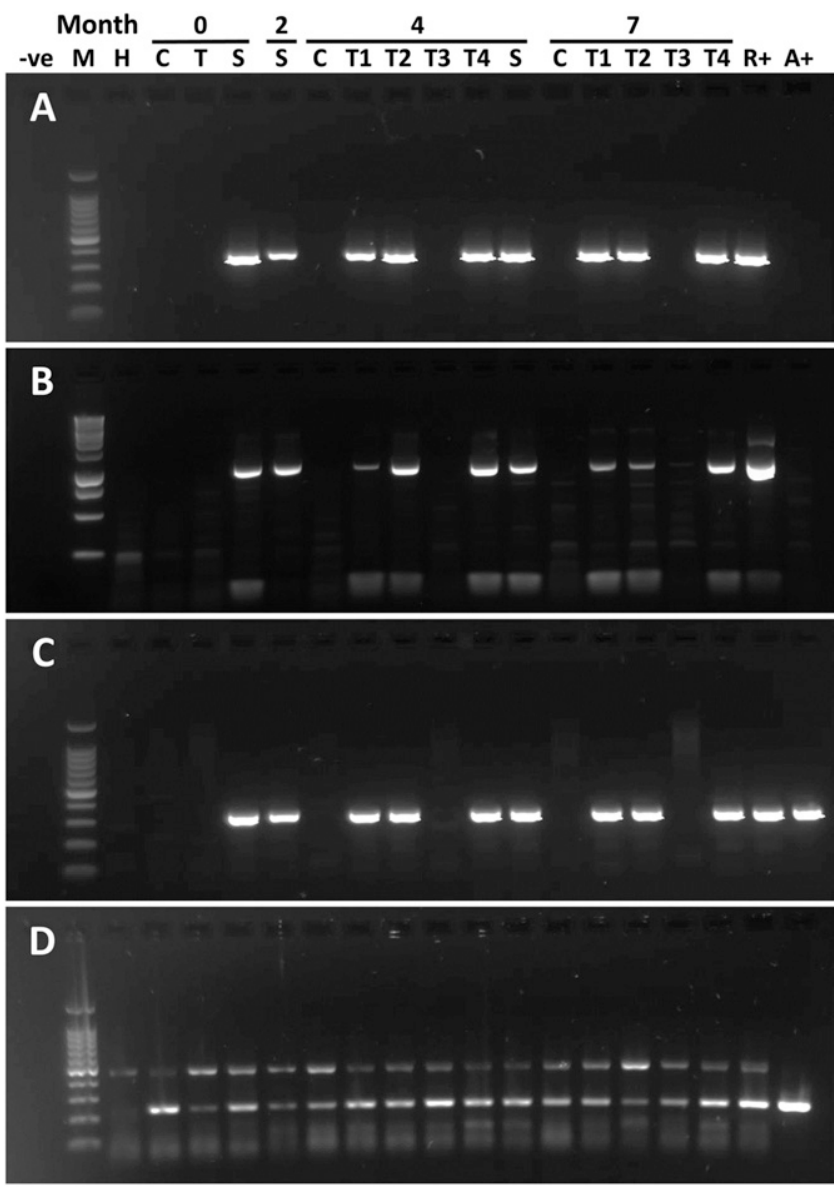

Fig. 2. Gel-based PCR results for transmission samples. A, Standard diagnostic combination RSC1fFwd-RSC1eRev. B, Early diagnostic combination KB20AfwdKB36Arev. C, Diagnostic combination RSNCPaF-RSNCPCR developed to detect isolates from the Alotau region. D, Endogenous test based on ScPFK5F1ScPFK5R1. Lanes from left to right are as follows: no template control (-ve); DNA size marker (M) either 100-bp ladder in (A), (B), and (D) or 1-kb ladder in (C); healthy Ragnar from the quarantine glasshouse in Australia $(\mathrm{H})$. Transmission samples are as follows: control (C), test (T), and source (S) cages at the commencement of the trial; source cage at the time of vector transfer (2 months); control, test, and source cages at the first inspection (4 months); and control and test cages at the second inspection (7 months). The four plants from the test cage (T1 to T4) were sampled individually. Ramu stunt-infected positive controls are Ragnar $(\mathrm{R}+)$ and Alotau-26 (A+). at $140,000 \times g$ in a Beckman 45Ti rotor (Beckman Instruments, Fullerton, CA). The supernatant was filtered through a PALL Acrodisc disposable 25-mm glass-fiber syringe filter (Pall Corporation, Ann Arbor, MI) and $500 \mu \mathrm{l}$ of $10 \%$ Triton X-100 was added. The preparation was centrifuged again for 45 min at $140,000 \times g$ in a Beckman $45 \mathrm{Ti}$ rotor. The pellet was resuspended in $200 \mu \mathrm{l}$ of $50 \mathrm{mM}$ sodium phosphate buffer, $\mathrm{pH} 7$, transferred to a microfuge tube, and briefly clarified by centrifuging at $15,800 \times g$ for $1 \mathrm{~min}$.

Viral proteins were separated by PAGE on Invitrogen NuPAGE 4-12\% Bis-Tris gels under reducing conditions with MES SDS running buffer. Invitrogen NuPAGE reagents including LDS sample buffer, reducing agent, and Mark12 unstained standards were used. Proteins were detected by silver staining with the Pierce silver stain kit (supplied by Thermo Fisher Scientific).

\section{Results}

Transmission experiment. During the 7-month experiment, source, test, and control plants were monitored with the diagnostic test and symptom descriptions were recorded. Samples of $E$. flavipes were also monitored with the diagnostic test. The experimental timeline, symptoms, and diagnostic screening results are summarized in Table 2 .

The five plants of cultivar Ragnar taken from a known disease source and established in the source cage showed the characteristic symptoms of Ramu stunt disease: pale green streaks and flecks on their leaves (Fig. 1A). Diagnostic testing in March at the start of the experiment confirmed their disease status and they continued to test positive throughout the trial. When the plants were first inspected in July (4 months), the source plants were very unthrifty; by the final inspection in October (7 months), all of the source plants were dead.

E. flavipes collected directly from the field was considered free of RmSV after a subsample of 40 tested negative for the virus (Table 2). The insects were introduced to the disease source cage to feed for up to 2 months and establish a vuliferous population. Diagnostic testing of a subsample showed that $68 \%$ had acquired RmSV (Table 2). The E. flavipes were collected and transferred to the plants in the test cage. Insect mortality in the test cage was high; within 2 months, numbers had greatly dropped and there were no surviving insects by the second inspection.

The control plants continued to test negative throughout the trial, although only four plants survived the trial. At the first inspection (4 months after commencing and 2 months after the final exposure to viruliferous $E$. flavipes), three of the four surviving test plants showed faint leaf streaks typical of Ramu stunt disease (Fig. 1B) and leaves from these tested positive with the diagnostic test, confirming that the virus had been successfully transmitted. The plant with no obvious symptoms (test plant T3) tested negative for RmSV. When the regrowth was inspected at 7 months, the characteristic streaks were difficult to see, but many stalks were thin, stunted, and grassy with thin pale leaves (Fig. 1C). Stunted and nonstunted stalks were tested separately and no nonstunted stalk gave a positive diagnostic test result (data not shown). The same three plants that tested positive previously were again positive and test plant T3 was still negative.

Confirmation that $E$. flavipes is the vector of $\mathbf{R m S V}$. Diagnostic testing using three primer combinations confirmed that RmSV was successfully transmitted to the test plants. The three combinations amplify from two viral genome segments, RNA 6 and RNA 1. Examples of gel-based screening results are presented in Figure 2. The endogenous test (Fig. 2D) confirmed that the RNA extracted from dried irradiated leaf samples was of sufficient quality for RT-PCR.

To confirm that there was consistent transmission of the same viral isolate throughout the experiment, the entire $1.2 \mathrm{~kb}$ of RNA 6 was sequenced from representative samples (Table 3). The RNA 6 sequence from a female E. flavipes from the source cage was included (GenBank accession MK262794). The COI sequence from this insect was also deposited in GenBank (accession MK262793). RNA 6 sequences were compared with reference isolates from Ragnar and the RNA 6 sequence determined by Mollov et al. (2016) (GenBank accession KR094119). The viral sequences from the source 
plants, vector, and test plants shared 99.3 to $100 \%$ similarity, in the same range as that seen between the transmission samples and the reference isolates (Table 3).

The third technique used to confirm transmission success was protein based. Viral minipreparations extracted from selected plants from the transmission experiment were separated by PAGE and silver stained (Fig. 3). All RmSV-infected plants displayed a characteristic protein with a molecular mass of $33 \mathrm{kDa}$ that was not present in healthy Ragnar sourced from Australia, control plants, test plants prior to exposure to the vector, or in test plant T3 after exposure. Test plant $\mathrm{T} 3$ also did not test positive with any diagnostic test after exposure to the vector.
Survey results. During a Papua New Guinea-wide survey in 2001, plants with suspected Ramu stunt symptoms were observed at 25 sites. However, diagnostic testing initially found only one to be positive, from a commercial sugarcane sample (cultivar Ragnar) from the RAIL estate. Plant samples with possible viral symptoms collected during surveys in Torres Strait in Northern Australia and Indonesia where Ramu stunt disease has not been recorded were also tested, with none found positive for the virus.

For the later surveys carried out after 2009, there was a greater appreciation of Ramu stunt disease symptoms; however, leaves showing a wide range of yellowing, streaking, and flecking were still sampled because they represented a valuable scientific collection.

Table 3. Nucleotide homology shared between RNA 6 segments from transmission samples and reference isolates ${ }^{\mathrm{a}}$

\begin{tabular}{|c|c|c|c|c|c|c|c|c|c|c|c|c|c|}
\hline \multirow[b]{2}{*}{ Sample } & \multicolumn{4}{|c|}{ Source cage } & \multicolumn{3}{|c|}{$\begin{array}{c}\text { Test plants at first } \\
\text { inspection }\end{array}$} & \multicolumn{3}{|c|}{$\begin{array}{l}\text { Test plants at second } \\
\text { inspection }\end{array}$} & \multicolumn{3}{|c|}{ Reference sequences } \\
\hline & $\begin{array}{c}E . \\
\text { flavipes }\end{array}$ & $\begin{array}{l}\text { Source: } \\
0 \text { mo }\end{array}$ & $\begin{array}{l}\text { Source: } \\
2 \text { mo }\end{array}$ & $\begin{array}{l}\text { Source: } \\
4 \mathrm{mo}\end{array}$ & $\begin{array}{l}\text { Test 1: } \\
4 \text { mo }\end{array}$ & $\begin{array}{l}\text { Test 2: } \\
4 \text { mo }\end{array}$ & $\begin{array}{l}\text { Test 4: } \\
4 \text { mo }\end{array}$ & $\begin{array}{l}\text { Test 1: } \\
7 \text { mo }\end{array}$ & $\begin{array}{l}\text { Test 2: } \\
7 \mathrm{mo}\end{array}$ & $\begin{array}{l}\text { Test 4: } \\
7 \text { mo }\end{array}$ & $\underset{2001}{\text { Ragnar }}$ & $\underset{2016}{\text { Ragnar }}$ & KR094119 \\
\hline E. flavipes & & 3 & 5 & 4 & 6 & 4 & 6 & 3 & 6 & 5 & 3 & 2 & 5 \\
\hline $\begin{array}{l}\text { Source: } \\
0 \text { mo }\end{array}$ & 99.8 & & 2 & 1 & 7 & 1 & 7 & 0 & 5 & 6 & 0 & 3 & 2 \\
\hline $\begin{array}{l}\text { Source: } \\
2 \mathrm{mo}\end{array}$ & 99.6 & 99.8 & & 3 & 9 & 3 & 9 & 2 & 7 & 8 & 2 & 5 & 4 \\
\hline $\begin{array}{l}\text { Source: } \\
4 \mathrm{mo}\end{array}$ & 99.7 & 99.9 & 99.8 & & 8 & 2 & 8 & 1 & 6 & 7 & 1 & 4 & 3 \\
\hline $\begin{array}{l}\text { Test 1: } \\
4 \text { mo }\end{array}$ & 99.5 & 99.4 & 99.3 & 99.3 & & 8 & 0 & 7 & 2 & 3 & 7 & 6 & 9 \\
\hline $\begin{array}{r}\text { Test 2: } \\
4 \text { mo }\end{array}$ & 99.7 & 99.9 & 99.8 & 99.8 & 99.3 & & 8 & 1 & 6 & 7 & 1 & 4 & 3 \\
\hline $\begin{array}{l}\text { Test 4: } \\
4 \text { mo }\end{array}$ & 99.5 & 99.4 & 99.3 & 99.3 & 100 & 99.3 & & 7 & 2 & 3 & 7 & 6 & 9 \\
\hline $\begin{array}{l}\text { Test 1: } \\
7 \text { mo }\end{array}$ & 99.8 & 100 & 99.8 & 99.9 & 99.4 & 99.9 & 99.4 & & 5 & 6 & 0 & 3 & 2 \\
\hline $\begin{array}{l}\text { Test 2: } \\
7 \mathrm{mo}\end{array}$ & 99.5 & 99.6 & 99.4 & 99.5 & 99.8 & 99.5 & 99.8 & 99.6 & & 5 & 5 & 6 & 7 \\
\hline $\begin{array}{l}\text { Test 4: } \\
7 \text { mo }\end{array}$ & 99.6 & 99.5 & 99.3 & 99.4 & 99.8 & 99.4 & 99.8 & 99.5 & 99.6 & & 6 & 5 & 8 \\
\hline $\begin{array}{l}\text { Ragnar } \\
2001\end{array}$ & 99.8 & 100 & 99.8 & 99.9 & 99.4 & 99.9 & 99.4 & 100 & 99.6 & 99.5 & & 3 & 2 \\
\hline $\begin{array}{c}\text { Ragnar } \\
2016\end{array}$ & 99.8 & 99.8 & 99.6 & 99.7 & 99.5 & 99.7 & 99.5 & 99.8 & 99.5 & 99.6 & 99.8 & & 5 \\
\hline KR094119 & 99.6 & 99.8 & 99.7 & 99.8 & 99.3 & 99.8 & 99.3 & 99.8 & 99.4 & 99.3 & 99.8 & 99.6 & \\
\hline
\end{tabular}

a The upper half of the table shows the number of nonidentical nucleotides across the 1,201-bp segment; the lower half of the table shows the percent sequence identity.

Month 2

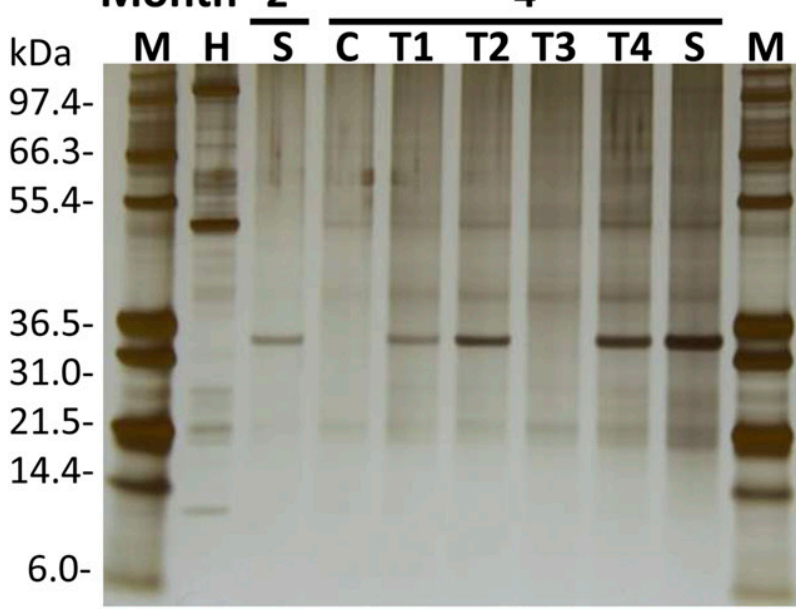

$2 \frac{7}{5}$

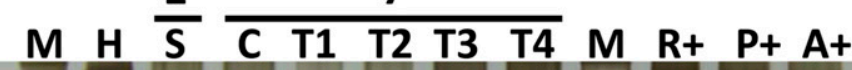

Fig. 3. Silver-stained, polyacrylamide gels showing separation of viral proteins. Protein size markers are labeled M with the approximate molecular mass (in kilodaltons) shown on the left. $\mathrm{H}$ represents healthy Ragnar from the quarantine glasshouse in Australia. Transmission samples are as follows: source cage (S) at the time of vector transfer (2 months); control (C), test (T), and source cages at the first inspection (4 months); and control and test cages at the second inspection (7 months). The four plants from the test cage (T1 to T4) were sampled individually. Ramu stunt-infected positive controls are Ragnar (R+), PN97-54 ( + +), and Alotau-26 (A+), which all show the characteristic 33-kDa band (arrow). 
From these surveys, nine samples tested positive for RmSV, all $S$. officinarum from village gardens in the Ramu Valley region. A further three positive samples were collected from a home garden on the RAIL estate. The location and sampling details of the positive samples are listed in Tables 4 and 5.

The 2001 Papua New Guinea-wide survey reported finding two samples from the Alotau region with good symptoms of Ramu stunt disease, but they did not test positive with the diagnostic test based on RSC1fFwd-RSC1eRev nor the earlier test based on KB20AfwdKB36Arev. The Alotau region was revisited in 2013, and a further four S. officinarum canes were identified in a garden in Bitu Village, again with good symptoms but failing to test positive (Fig. 2A and B). Viral minipreparations separated by PAGE displayed the characteristic 33-kDa protein, suggesting that they were infected with a virus containing a capsid protein of a size comparable to RmSV (Fig. 3). RNA 6 sequences were aligned to enable a new primer set, RSNCPaF-RSNCPcR (Fig. 2C; Table 1), to be designed. All 13 survey samples previously identified as positive, as well as the two Alotau samples from 2001 and the four from 2013, tested positive with the new primers. There were no other new detections made from the collection.

Phylogenetic analyses. The genome segment (RNA 6) used to verify isolate stability throughout the transmission experiment was the same target region for phylogenetic analyses of survey samples. Figure 4 shows the genetic relationship between 33 isolates based on the 1.2-kb RNA 6 segment. The analysis includes the oldest Ragnar isolate in the collection, from the 2001 Papua New Guinea-wide survey, and the most recent, sampled in November 2016 and the reference sequence KR094119. The length of RNA 6 was 1,201 bp for the RAIL and Ramu Valley isolates and 1,208 bp for the Alotau isolates. Figure 4 shows a clear clustering pattern based on host and location. Isolates from commercial canes and KR094119 shared 99.5 to $100 \%$ nucleotide sequence identity, similar to the range reported in Table 3. Isolates from $S$. officinarum from the Ramu Valley shared 95.5 to 96.5\% nucleotide sequence identity with the commercial cane isolates. The three $S$. officinarum isolates from a home garden on the RAIL estate formed a separate cluster close to the Ramu Valley and commercial cane isolates. The Alotau isolates were more diverse, sharing only 80.6 to $82.0 \%$ nucleotide similarity with the northern isolates.

\section{Discussion}

Since recognition in the mid-1980s that Ramu stunt is a severe and devastating disease of sugarcane, the process to identify the causal agent has been slow. Major breakthroughs were the identification of the insect vector as E. flavipes (Kuniata et al. 1994), preliminary

Table 4. Collection details for Ramu stunt virus (RmSV)-positive samples from commercial cane isolates from the Ramu Agri Industries Limited (RAIL) estate, collected between 2001 and 2016

\begin{tabular}{|c|c|c|c|c|}
\hline Cultivar host & Year & Estate details $^{\mathbf{a}}$ & RAIL estate block number & GenBank accession $^{\text {b }}$ \\
\hline Ragnar & 2001 & PNG survey & Unknown & MK262795 \\
\hline N7 & 2006 & Unknown & DS502 & MK262796 \\
\hline Q85N1802 & 2006 & Unknown & Unknown & MK262797 \\
\hline PN93-18 & 2007 & Quarantine & N/A & MK262798 \\
\hline BJ7013 & 2007 & RAIL screening trial & CN107 & MK262799 \\
\hline Q125 & 2007 & RAIL screening trial & CN107 & MK262800 \\
\hline Ragnar & 2008 & Unknown & Unknown & MK262801 \\
\hline PN97-54 & 2012 & Nursery & ES206 & MK262802 \\
\hline BJ7013 & 2013 & SRA screening trial & DS505a & MK262803 \\
\hline PN97-57 & 2014 & RAIL screening trial spreader row & BN401 & MK262804 \\
\hline PN92-339 & 2014 & Commercial nursery & DS409 & MK262805 \\
\hline Q198 & 2014 & Commercial nursery & DS408 & MK262806 \\
\hline R570 & 2014 & Commercial field & EN102 & MK262807 \\
\hline R570 & 2016 & Commercial field & BS914 & MK262808 \\
\hline Ragnar & 2016 & SRA screening trial spreader row & BN401 & MK262809 \\
\hline
\end{tabular}

a PNG = Papua New Guinea, N/A = not applicable, and SRA = Sugar Research Australia.

${ }^{\mathrm{b}}$ The GenBank accession number for each RNA 6 sequence is given. The RNA 6 sequences were used in the RmSV phylogenetic analysis.

Table 5. Collection details for Saccharum officinarum isolates from village gardens, collected between 2001 and 2016

\begin{tabular}{|c|c|c|c|c|c|}
\hline Code & Year & Location $^{a}$ & GPS $S^{\mathbf{b}}$ & GPS $\mathbf{E}^{\mathbf{b}}$ & GenBank accession \\
\hline Alotau-220 & 2001 & Alotau Harbor, PNG survey & 10.3080 & 150.4537 & MK262810 \\
\hline Alotau-224 & 2001 & Bitu Village, Alotau, PNG survey & 10.2950 & 150.3951 & MK262811 \\
\hline Block 48-3 & 2009 & Block 48, Kesewai, Ramu Valley & 5.7477 & 145.5720 & MK262812 \\
\hline Block 48-9 & 2009 & Block 48, Kesewai, Ramu Valley & 5.7477 & 145.5720 & MK262813 \\
\hline Block 48-10 & 2009 & Block 48, Kesewai, Ramu Valley & 5.7477 & 145.5720 & MK262814 \\
\hline Block 48-22 & 2010 & Block 48, Kesewai, Ramu Valley & 5.7477 & 145.5720 & MK262815 \\
\hline Block 48-23 & 2010 & Block 48, Kesewai, Ramu Valley & 5.7477 & 145.5720 & MK262816 \\
\hline Sausi-13 & 2010 & Sausi Evangelical Church, Ramu Valley & 5.6605 & 145.4979 & MK262817 \\
\hline Asas-10 & 2011 & Asas Apostolic Church, Ramu Valley & 5.7113 & 145.5581 & MK262818 \\
\hline Wamba-2 & 2012 & Balus Hauslain, RAIL & 5.9562 & 145.8912 & MK262819 \\
\hline Wamba-3 & 2012 & Balus Hauslain, RAIL & 5.9562 & 145.8912 & MK262820 \\
\hline Wamba-4 & 2012 & Balus Hauslain, RAIL & 5.9562 & 145.8912 & MK262821 \\
\hline Alotau-26 & 2013 & Bitu Village, Alotau & 10.2921 & 150.3945 & MK262822 \\
\hline Alotau-27 & 2013 & Bitu Village, Alotau & 10.2921 & 150.3945 & MK262823 \\
\hline Alotau-28 & 2013 & Bitu Village, Alotau & 10.2921 & 150.3945 & MK262824 \\
\hline Alotau-29 & 2013 & Bitu Village, Alotau & 10.2921 & 150.3945 & MK262825 \\
\hline Asas-26 & 2016 & Asas, Ramu Valley & 5.7269 & 145.5622 & MK262826 \\
\hline Asas-27 & 2016 & Asas, Ramu Valley & 5.7269 & 145.5622 & MK262827 \\
\hline
\end{tabular}

a PNG = Papua New Guinea and RAIL = Ramu Agri Industries Limited.

${ }^{\mathrm{b}}$ GPS coordinates for South and East in decimal degrees.

${ }^{\mathrm{c}}$ The GenBank accession number for each RNA 6 sequence is given. The RNA 6 sequences were used in the Ramu stunt virus phylogenetic analysis. 
molecular evidence suggesting a tenuivirus-like causal agent (Braithwaite et al. 2007), validation of the diagnostic test allowing the symptoms and virus presence to be linked (Braithwaite et al. 2012), and sequencing of the complete genome of the tenuivirus provisionally named RmSV by Mollov et al. (2016). The final step has been our confirmation that E. flavipes is able to transmit the virus to healthy sugarcane through use of the diagnostic assay, molecular sequencing, and viral protein characterization. The diagnostic assay results agreed with the presence of visual symptoms in the test plants.

The experimental setup had some limitations that reflected the facilities available on the RAIL estate where the trial was performed. Because no glasshouses or insectary capable of rearing E. flavipes was available, E. flavipes had to be collected directly from the field. Efforts were made to source E. flavipes from the southern side of the estate, approximately $5 \mathrm{~km}$ from the diseased plant source on the northern side. The plants from which $E$. flavipes were collected did not display any symptoms of Ramu stunt disease and diagnostic testing showed a subsample of E. flavipes to be free of RmSV at the start of the trial.

Although the transmission results confirm that E. flavipes can vector RmSV, the experiment does not prove that E. flavipes is the only vector. However, preliminary observations described in Kuniata et al. (1994) indicated no other insect vector. During our experiment, pink sugarcane mealybugs [Saccharicoccus sacchari (Cockerell)] were seen on both the test and control plants, but no symptoms of Ramu stunt disease were observed on the control plants. The results also do not rule out E. flavipes vectoring other disease agents in addition to the tenuivirus. However, when Mollov et al. (2016) used

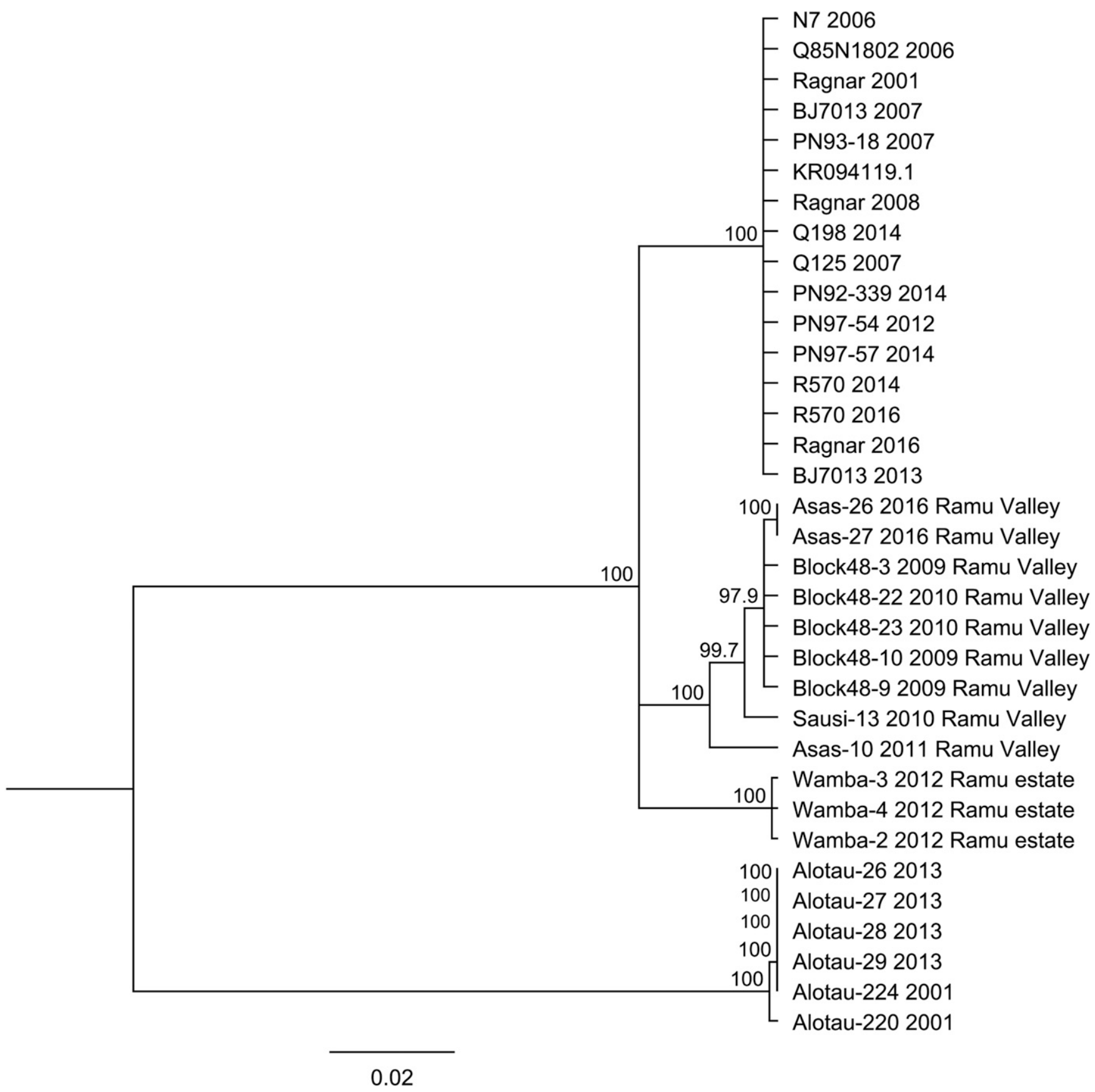

Fig. 4. Phylogenetic tree of Ramu stunt virus (RmSV) RNA 6 sequences from the Ramu Agri Industries Limited estate, Ramu Valley, and Alotau region. Sequences were generated from the viral isolates listed in Tables 4 and 5 and are named after the host cultivar (if from a commercial sugarcane) or geographic location (if from Saccharum officinarum) and year of collection. Only branches with a support threshold $>80 \%$ are shown. Values at the nodes indicate the percentage of bootstrap support. KR094119 (Mollov et al. 2016 ) is included as the RNA 6 reference sequence. 
infected Ragnar originally sourced from RAIL for high-throughput sequencing, only the six RNAs of the RmSV genome were detected and no other plant virus-related contigs were identified. With no access to sterile growth media, the transmission experiment had to be performed using plants grown in soil, allowing for the possibility of a soilborne factor interacting with the virus. However, the experimental material used by Mollov et al. (2016) was propagated at the U.S. Department of Agriculture Animal and Plant Health Inspection Service Plant Germplasm Quarantine facility in Beltsville, Maryland, far removed from any interfering biological agents.

Despite the limitations to our experiment, RmSV was successfully transmitted from infected to Ramu stunt-free plants that went on to display the characteristic symptoms of Ramu stunt infection. No symptoms were observed in the control plants. One plant in each of the test and control cages died during the trial, possibly as a result of poor growing conditions inside the cages. Nucleic acid- and protein-based testing was used to confirm that the test plants were infected with the same virus found in the source plants. Nucleic acid-based confirmation used RT-PCR screening with three primer combinations from two coding regions and partial genome sequencing of one segment. Protein-based confirmation was performed through viral minipurifications, followed by PAGE.

Disease surveys throughout Papua New Guinea have been considered an important biosecurity tool for the Australian sugar industry for many years. Sampling of sugarcane leaves suspected to be infected with Ramu stunt disease started in 2001, although no diagnostic test was available at that time. This early disease survey declared Ramu stunt to be widespread and a high risk to the Australian sugar industry. It was not until 2006 that survey samples could be screened by a molecular test, initially the first-generation test of Braithwaite et al. (2007), then the primers described here, RSC1fFwd-RSCleRev and RSNCPaF-RSNCPcR. Validation of the diagnostic test using standards from a resistance screening trial (Braithwaite et al. 2012) finally helped to link the symptoms with the presence of the virus. Although pale yellow-green leaf stripes of irregular length and width appear to be characteristic of Ramu stunt, other symptoms such as leaf flecks and mosaic, stunting, yellowing, grassiness, and shoot death are not unique to Ramu stunt and can also be associated with other pest, disease, and physiological conditions (Waller et al. 1987). We have been able to compare the oldest isolate in our collection, collected from cultivar Ragnar in 2001, to an isolate collected from Ragnar in 2016 and show negligible sequence change. That RmSV has been consistently detected in commercial and research sugarcanes of many cultivars showing Ramu stunt symptoms over 15 years indicates a strong association between the virus and the disease.

Diagnostic screening of survey samples initially detected the disease in garden canes only from the RAIL estate and the Ramu Valley, making the disease much less prevalent across Papua New Guinea than initially claimed. The discrepancy between survey results based on symptoms and results based on diagnostic testing could be explained by the presence of sequence variation within the primer binding sites. Performing viral minipreparations and PAGE is too slow and labor intensive to be used for high-throughput diagnostics, but it was proven to be a useful research tool to confirm doubtful samples. This was how two isolates from Alotau, which displayed good symptoms but tested negative by RT-PCR, were shown to be infected. The presence of different genotypes in the Alotau region was later confirmed in 2013 when a follow-up survey was made to collect more samples. We then developed a set of diagnostic RTPCR primers to account for the genotype variation. The biosecurity implications of pathogen variation are significant. Much of the contingency planning and resistance screening efforts could become outdated if a second variant of the pathogen becomes prevalent.

The 2001 Papua New Guinea survey found specimens of Eumetopina spp. at almost every site visited (Magarey et al. 2002). E. flavipes occurs from Papua New Guinea through to islands in the Torres Strait onto the Northern Peninsula Area of Cape York Peninsula on mainland Australia (Grimshaw and Donaldson 2007), but it is not known from commercial sugarcane further south in Australia. $E$. flavipes represents a considerable biosecurity threat to Australia if an incursion of the virus is found in commercial sugarcane crops. E. flavipes is also found on sugarcane in Malaysia, Philippines, Indonesia, and New Caledonia (Fitzgibbon et al. 1999). In addition to the 2001 Papua New Guinea survey, there were also extensive surveys of Indonesia and Northern Australia in 2003 (Magarey et al. 2003) and Torres Strait and Cape York Peninsula in 2004 (Magarey et al. 2004). Samples showing possible symptoms of viral infections such as yellowing, streaking, and flecking were screened, but none tested positive for RmSV. Despite there being no confirmed detections, the risk of E. flavipes spreading Ramu stunt outside of Papua New Guinea still remains high. Our results show that the diagnostic test works well on E. flavipes, providing a useful biosecurity tool to manage potential incursions.

In conclusion, a long-term collaborative research program has contributed to an improved understanding of Ramu stunt diagnosis, distribution, genotype variation, and transmission. The diagnostic test can be used at RAIL as part of their disease-management program, in future disease surveys, by sugar industries wishing to import sugarcane germplasm from Papua New Guinea, and by neighboring sugar industries to confirm suspected disease outbreaks. Further efforts are needed to monitor for the appearance and spread of new variants within Papua New Guinea and to understand the biosecurity implications of these variants.

\section{Acknowledgments}

Many pathology and entomology staff members from SRA and RAIL have assisted with the laboratory and field work but we are particularly grateful to Elizabeth Wilson from SRA and Wamba Batimane, Simeon Yamang, and Baina Rutu from RAIL. Nicole Thompson, Barry Croft, and Chuong Ngo critically reviewed the manuscript.

\section{Literature Cited}

Braithwaite, K. S., Croft, B. J., and Magarey, R. C. 2007. Progress in identifying the cause of Ramu stunt disease of sugarcane. Proc. Aust. Soc. Sugar Cane Technol. 29:235-241.

Braithwaite, K. S., Kombukon, R., Kuniata, L. S., and Magarey, R. C. 2012. Ramu stunt: Resistance screening and validation of the diagnostic test. Proc. Aust. Soc. Sugar Cane Technol. 34.

Cronjé, C. P. R., Bailey, R. A., Jones, P., and Suma, S. 1999. The phytoplasma associated with Ramu stunt disease of sugarcane is closely related to the white leaf phytoplasma group. Plant Dis. 83:588.

Daniels, J., and Roach, B. T. 1987. Taxonomy and evolution. Pages 7-84 in: Sugarcane Improvement Through Breeding. D. J. Heinz, ed. Elsevier Press, Amsterdam, Netherlands.

de Miranda, J., Hernandez, M., Hull, R., and Espinoza, A. M. 1994. Sequence analysis of rice hoja blanca virus RNA 3. J. Gen. Virol. 75:2127-2132.

Eastwood, D. 1990. Ramu stunt disease: Development and consequences at Ramu Sugar Ltd. Sugar Cane 1990:15-19.

Fitzgibbon, F., Allsopp, P. G., and De Barro, P. J. 1999. Chomping, boring and sucking on our doorstep-The menace from the north. Proc. Aust. Soc. Sugar Cane Technol. 21:149-155.

Folmer, O., Black, M., Hoeh, W., Lutz, R., and Vrijenhoek, R. 1994. DNA primers for amplification of mitochondrial cytochrome $c$ oxidase subunit I from diverse metazoan invertebrates. Mol. Mar. Biol. Biotechnol. 3:294-299.

Grimshaw, J. F., and Donaldson, J. F. 2007. Records of two sugarcane pest Eumetopina flavipes Muir (Hemiptera: Delphacidae) and Chilo terrenellus Pagenstecher (Lepidoptera: Pyralidae) from the Torres Strait and far north Queensland. Aust. J. Entomol. 46:35-39.

Jones, P., Antoniw, J. F., and Eastwood, D. 1989. Investigations into the aetiology of Ramu stunt, a new sugarcane disease in Papua New Guinea. L'Agron. Trop. 44:179-184.

Kuniata, L. S., Magarey, R. C., Rauka, G. R., Suma, S., and Bull, J. I. 2010 Screening for Ramu stunt resistance at Ramu Agri-Industries, GUSAP, PNG 1986-2008. Proc. Aust. Soc. Sugar Cane Technol. 32:312-321.

Kuniata, L. S., Young, G. R., Pais, E., Jones, P., and Nagaraja, H. 1994 Preliminary observations on Eumetopina sp. (Hemiptera: Delphacidae) as a vector of Ramu stunt disease of sugarcane in Papua New Guinea. J. Aust. Entomol. Soc. 33:185-186.

Magarey, R. C., Kuniata, L. S., Croft, B. J., Chandler, K. J., Irawan, Kristini, A., Spall, V. E., Samson, P. R., and Allsopp, P. G. 2003. International activities to minimise industry losses from exotic pests and diseases. Proc. Aust. Soc. Sugar Cane Technol. 25 (CD-ROM).

Magarey, R. C., Kuniata, L. S., Samson, P. R., Irawan, and Rauka, G. R. 2004 Quarantine survey of Cape York Peninsula and the Torres Strait-2003. Proc. Aust. Soc. Sugar Cane Technol. 26 (CD-ROM).

Magarey, R. C., Suma, S., Irawan, Kuniata, L. S., and Allsopp, P. G. 2002. Sik na binatang bilong suka- Diseases and pests encountered during a survey of Saccharum germplasm 'in the wild' in Papua New Guinea. Proc. Aust. Soc. Sugar Cane Technol. 24 (CD-ROM). 
Mollov, D., Maroon-Lango, C., and Kuniata, L. 2016. Detection by next generation sequencing of a multi-segmented viral genome from sugarcane associated with Ramu stunt disease. Virus Genes 52:152-155.

Plant Health Australia. 2016. Biosecurity Plan for the Sugarcane Industry (Version 3.0, May 2016). Plant Health Australia, Canberra.

Rauka, G. B., Magarey, R. C., and Kuniata, L. S. 2005. The current disease situation on the commercial estate of Ramu Sugar, Papua New Guinea. Proc. Aust. Soc. Sugar Cane Technol. 27:266-272.

Suma, S., and Jones, P. 2000. Ramu stunt. Pages 226-230 in: A Guide to Sugarcane Diseases. P. Rott, R. A. Bailey, J. C. Comstock, B. J. Croft, and A. S. Saumtally, eds. Agricultural Research for Development and International Society of Sugar Cane Technologists, Montpellier, France.

Virtudazo, E. V., Nakamura, H., and Kakishima, M. 2001. Phylogenetic analysis of sugarcane rusts based on sequences of ITS, 5.8 S rDNA and D1/D2 regions of LSU rDNA. J. Gen. Plant Pathol. 67:28-36.

Waller, J. M., Egan, B. T., and Eastwood, D. 1987. Ramu stunt, an important new sugarcane disease in Papua New Guinea. Trop. Pest Manage. 33:347-349.

Zhu, L., Zhang, J., Chen, Y., Pan, H., and Ming, R. 2013. Identification and genes expression analysis of ATP-dependent phosphofructokinase family members among three Saccharum species. Funct. Plant Biol. 40:369-378. 